\title{
PENGARUH COACHING: SELF HEALING TERHADAP TINGKAT STRES DAN KADAR KORTISOL PADA PASIEN GAGAL GINJAL KRONIS DENGAN HEMODIALISIS
}

\author{
Nita Arisanti Yulanda ${ }^{1}$, Herman ${ }^{2)}$ \\ ${ }^{1}$ Universitas Tanjungpura Pontianak \\ $e$-mail : nita.arisantiyulianda@ners.untan.ac.id
}

\begin{abstract}
ABSTRAK
Gagal Ginjal Kronis (GGK) merupakan gangguan fungsi renal yang progresif dan irreversible yang memerlukan tindakan hemodialisis dan memiliki keterbatasan dalam kehidupannya. Keterbatasan ini mengakibatkan pasien rentan terhadap stres. Salah satu terapi self healing: mind body and spirit menggunakan do'a dan zikir mampu meningkatkan spiritual value dan mempengaruhi peningkatan kepribadian. Terapi ini mampu merubah stres negatif (distres) menjadi stres positif (eustres) dan perubahan respon biologis oleh potensi penurunan kortisol. Tujuan penelitian menganalisis pengaruh self healing terhadap tingkar stres dan kadar kortisol pasien gagal ginjal yang menjalani hemodialisis. Desain penelitian ini adalah quasy eksperimental (pre post test with control group design). Populasi penelitian adalah pasien gagal ginjal yang menjalani hemodialisis di dua Rumah Sakit yang berbeda di Kalimantan Barat namun memiliki tipe yang sama, yaitu tipe B. Jumlah sampel 40 responden yang terbagi menjadi 2 kelompok (intervensi dan kontrol) masing - masing kelompok penelitian terdapat 20 responden yang sesuai dengan kriteria inklusi penelitian. Tehnik pengambilan sampel menggunakan purposive sampling. Pengumpulan data menggunakan instrumen DASS 42 dan pengukuran kadar kortisol dengan Elisa Kit. Hasil uji Independent T-test kedua kelompok pada variabel tingkat stres memiliki hubungan bermakna $(p=0,004)$ sedangkan pada kadar kortisol memiliki hubungan tidak bermakna $(p=0,148)$. Terdapat pengaruh self healing pada tingkat stres pasien hemodialisis. Sebagai seorang perawat dalam melaksanakan asuhan keperawatan juga harus memperhatikan kebutuhan spiritual klien yang mampu menurunkan tingkat stres klien selama perawatan di rumah sakit.
\end{abstract}

Kata Kunci : Self Healing, Stres, Kortisol, GGK, Hemodialisis

\begin{abstract}
Chronic Renal Failure (CRF) is a progressive and irreversible renal function disorder that requires hemodialysis and CRF patients have several life limitation which make them vulnerable to stres. The self healing treatment:mind body and spirit therapy using prayers can increase spiritual value and influence personality improvement so that it changes negative stress (distress) to positive stress (eustress) and changes in biological responses by the effect for decreased cortisol. The purpose of the study was to analyze the effect of self healing on stress level and hemodialysis patient levels of cortisol in chronic renal failure patients. The design of this study is quasy experimental pretest-posttest with control group design. The population was hemodialysis patients in Hospitals Type B in West Kalimantan. The number of sample was 40 respondents who were divided into 2 groups (intervention and control). Purposive sampling technique was used to select the respondents. Data collection used DASS 42 instrument and measurement of cortisol levels. The results of the independent t-test of two groups on the stress level variable had a significant relationship $(p=0.004)$ whereas on cortisol levels the relationship was not significant $(p=0.148)$. There is a significant effect of self healing therapy on the stress
\end{abstract}


level of hemodialysis patients. As a nurse in carrying out nursing care must also consider the spiritual needs of clients who are able to reduce the level of client stress during treatment in the hospital

Keywords: Self Healing, Stres, Cortisol Level

\section{PENDAHULUAN}

Gagal ginjal kronis merupakan penyakit yang terjadi akibat kerusakan ginjal sehingga ginjal tidak mampu lagi mengeluarkan racun dan produk sisa dari darah, yang ditandai dengan adanya protein dalam urine dan penurunan laju filtrasi glomerulus selama lebih dari 3 bulan (Black\&Hawks, 2009). Selain sebagai organ eliminasi racun dan sisa produk ginjal juga memiliki peranan menjaga keseimbangan cairan tubuh, pembentukan sel darah merah, mengatur tekanan darah, mengatur asam basa ( $\mathrm{pH}$ darah) dan mengatur dalam pembentukan vitamin $\mathrm{D}$ aktif. Akan tetapi ketidakmampuan ginjal dalam menjalankan fungsinya dapat menyebabkan terjadinya gangguan keseimbangan cairan yang dapat mengakibatkan terjadinya bengkak seluruh tubuh, pernapasan menjadi sesak, penumpukan racun dan produk sisa darah dalam tubuh serta tidak terkendalinya tekanan darah pasien dengan gagal ginjal kronis, kondisi tersebut mampu mempengaruhi fungsi organ lain seperti jantung, hati, pencernaan bahkan hingga ke otak yang dapat berdampak pada peningkatan angka kesakitan (morbiditas) dan angka kematian (mortilitas) (Echder T\&Schriner, 2012)

Pada tahun 2016 data Badan Penyelenggara Jaminan Kesehatan (BPJS) mencatat penyakit ginjal kronis sebagai salah satu penyakit dengan pembiayaan terbesar kedua setelah penyakit jantung (Kemenkes RI, 2017). Indonesia merupakan Negara dengan tingkat penderita gagal ginjal yang cukup tinggi. Hasil survey data Indonesia Renal Registry
(IRR) tahun 2016 sebanyak 90\% pasien dengan penyakit ginjal kronis stadium 5 atau Chronic Kidney Disease Stage V, sedangkan data pasien yang menjalani homodialisa di tahun 2016 sebanyak 25.446 pasien baru dan 52.835 pasien aktif. Jumlah pasien bar uterus meningkat dari tahun ke tahun tercatat pada tahun 2017 sebanyak 30.831 pasien baru dan 77.892 pasien aktif yang menjalani hemodialisis dengan jenis kelamin sebagian besar laki - laki (56\%) (Report Indonesia Renal Registry (IRR), 2017)

Hemodialisis sebagai salah satu terapi pengganti ginjal yang dilakukan hampir sebagian besar pasien gagal ginjal kronis. Akan tetapi tindakan ini tidak sepenuhnya mampu mengganti fungsi ginjal. Ketika pasien sudah mulai menjalani hemodialisis maka saat itulah sebagian besar aspek kehidupan pasien telah berubah. Pasien harus menjalani hemodialisis secara rutin 2 - 3 kali seminggu, konsumsi obat obatan yang harus konsisten setiap hari (Kim, Y., Evangelista I.S., Phillips, L.R., Pavlish C.,\& Kopple, J.D, 2010)

Perubahan aspek kehidupan tidak hanya dirasakan oleh pasien namun juga oleh keluarga, karena keluarga dan orang lain akan memandang klien sebagai individu yang memiliki keterbatasan, hal ini disebabkan proses hemodialisis membutuhkan waktu tersendiri sehingga mengakibatkan kegiatan aktivitas social pasien berkurang, keterbatasan waktu yang dialami pasien hemodialisis juga mengakibatkan timbulnya rasa bersalah, frustasi bahkan bisa terjadi konflik (Smeltzer 
\& Bare, 2009). Keterbatasan yang dimiliki pasien hemodialisis akan rentang menimbulkan stres pada pasien hemodialisis. Stres yang dialami akibat ketidak seimbangan antara tuntutan dan sumber daya yang dimiliki individu, semakin tinggi kesenjangan terjadi mala akan semakin tinggi pula strees yang dialami individu (Yosep, 2014).

Kondisi stres yang dialami pasien dapat menimbulkan perubahan secara fisiologis, psikologis dan perilaku pada pasien yang mengakibatkan berkembangnya suatu penyakit. Stres yang dialami pasien secara berkepanjangan sesuai konsep psikoneuroimunologi melalui sel astrosit pada cortical dan amigdala pada system limbic berefek pada hipotalamus. Kemudian hipotalamus akan menghasilkan corticotropine Releasing Factor (CRF) yaitu pada sel basofilik. Sel basofilik tersebut akan mengekspresikan adrenal cortico Tropic Hormon (ACTH) yang akhirnya dapat mempengaruhi kelenjar korteks adrenal pada sel zona fasiculata kelenjar ini akan menghasilkan kortisol yang bersifat immunosuppressive (Ader, 2007). Stres yang terjadi dan terus menerus mengakibatkan hipotalamus mensekresi Corticotropin Relasing Hormone (CRH) yang akan menginduksi hipofisis anterior untuk mensekresi ACTH. ACTH yang adekuat dapat merangsang adrenal untuk mensekresi hormone kortisol, epinefrin dan nor-epinefrin dalam tanggapan tubuh untuk menekan stres yang diterimanya (Harris A., \& Secki, 2011)

Tingkat stres pada pasien gagal ginjal cukup tinggi sehingga perawat perlu mengetahui tingkat stres pada pasien gagal ginjal terminal yang menjalani hemodialisis. Kondisi ini diharapkan mampu membuat perawat lebih berempati dalam membantu menurunkan tingkat stres bukan hanya sekedar menjalakan rutinitas pemasangan alat hemodialisis. Karena adanya sikap empati dari perawat diharapkan mampu menurunkan tingkat stres yang dialami pasien hemodialisis (Sandra\&Dewi, 2012). Sesuai dengan penelitian Egan, et al. (2015) menunjukkan pasien gagal ginjal memerlukan dukungan spriritual. Kondisi Spiritual yang tinggi diharapkan mampu memberikan dampak yang baik bagi psikologis pasien.

Salah satu strategi untuk mengurangi stres adalah peningkatan koping agama, sesuai penelitian Terreri\&Glenwick (2013) dalam penelitian hubungan koping agama dan indikator kesehatan mental menunjukkan hasil yang signifikan. Salah satu bentuk koping agama adalah zikir.

Penelitian ini melakukan upaya peningkatan koping agama dengan menggunakan metode terapi komplementer self healing. Terapi komplementer adalah untuk mencapai kesembuhan secara mandiri/ self healing adalah terapi mind body and spirit. Pusat Nasional Pengobatan (NCCAM) menggunakan terapi mind body and spirit adalah sebagian dari terapi alternatif dan komplementer. Perspektif holistic, semangat merupakan bagian dari aspek kehidupan manusia yang merupakan bagian integral dari sejumlah terapi, karena aspek manusia merupakan bagian integral dari sejumlah terapi seperti doa, meditasi, dan yoga (Endra, EC., et.all, 2015). Penelitian Maimunah \& Retnowati (2011) mengungkapkan bahwa setiap individu mampu menghadapi dengan baik setiap stresor dengan penuh keyakinan karena Allah dengan bantuan zikir. Penyebutan Asma Allah berulang kali dengan zikir 
dipercaya umat muslim mampu menyembuhkan jiwa dan menyembuhkan berbagai penyakit. Pernyataan ini juga didukung hasil penelitian Suryani \& Nuraeni (2015) yang menjelaskan suatu teknik relaksasi yang didukung unsure keyakinann kepada Tuhan mampu meningkatkan respon relaksasi yang lebih kuat.

Zikir mampu membuat setiap individu merasa tenang sehingga mampu menekan kerja system saraf simpatis dan mengaktifkan kerja system syaraf parasimpatis (Saleh, 2010).

\section{METODOLOGI PENELITIAN}

Penelitian ini menggunakan rancangan penelitian quasi Experiment Pre-Post With Kontrol Group Design yaitu penerapan intervensi self healing (Do'a dan Zikir) terhadap tingkat stres dan kadar kortisol pasien hemodialisis. Pada penelitian ini kelompok intervensi diberikan self healing (Do'a dan Zikir) sedangkan kelompok kontrol hanya menerima perawatan rutin oleh dokter dan perawat di klinik.

Kelompok eksperimen menggunakan terapi komplementer yaitu dengan cara melakukan coaching (Bimbingan emosional dan pendidikan kesehatan) dengan menggunakan modul self healing yang berisikan bimbingan bagaimana cara berdo'a dan berzikir pada saat sakit. Pelaksanaan intervensi dilakukan selama 2 kali dalam seminggu dan dilakukan selama 4 minggu, ketika pelaksanaan tidak hanya responden yang diberikan intervensi namun keluarga juga mengikuti intervensi yang diberikan, sehingga diharapkan selama perawatan klien di rumah keluarga mampu menjadi pendamping klien selama pelaksanaan self healing.
Besar sampel yang diperlukan sebanyak 40 responden sesuai dengan criteria inklusi yaitu: klien gagal ginjal kronis yang kooperatif, klien beragama islam, klien dengan lama menjalani hemodialisis kurang dari 3 tahun. Jumlah sampel yang diperoleh dibagi menjadi 2 kelompok yaitu kontrol dan intervensi dengan masing masing kelompok sebanyak 20 responden.

Penelitian dilaksanakan di dua rumah sakit yang berbeda namun memiliki Tipe Rumah Sakit yang sama Yaitu tipe B. penelitian dilaksanakan mulai bulan juni agustus 2019.

Instrumen yang digunakan dalam penelitian ini menggunakan kuesioner Depression, Anxietas, Stres Scale 42 (DASS 42) yang dikeluarkan oleh Phychology Foundation Australia versi translasi ke bahasa Indonesia (Damanik, 2011) dan pengukuran kadar kortisol pasien yang bekerjasama dengan klinik Prodia Pontianak.

Penelitian ini telah lolos kaji etik dari Tim Kaji Etik Fakultas Kedokteran Universitas Tanjungpura Pontianak dengan Nomor surat lolos kaji etik. 5846/UN22.9/TA.00.03/2019.

\section{HASIL DAN PEMBAHASAN}

Sebagian besar responden pada kelompok intervensi berjenis kelamin perempuan (55\%), dengan usia sebagian besar 46-55 Tahun $(65 \%)$ dengan pendidikan sebagian besar SMP dan SMA (30\%) dengan lama sakit 2-3 tahun (65\%). Sedangkan pada kelompok kontrol sebagian besar responden berjenis kelamin laki-laki $(52,5 \%)$, berusia 46-55 Tahun (72,5\%) dan sebagian besar berpendidikan SMP $(32,5 \%)$ dengan lama sakit sekitar 2-3 tahun (65\%). 
Tabel 1. Distribusi Frekuensi

Karakteristik Responden

\begin{tabular}{lcc}
\hline Karakteristik & Intervensi & Kontrol \\
\cline { 2 - 3 } & Persentase & Persentase \\
\hline Jenis Kelamin & & \\
\hline Laki-laki & 45 & 65 \\
Perempuan & 55 & 35 \\
\hline Pendidikan & & \\
\hline SD & 20 & 30 \\
SMP & 30 & 35 \\
SMA & 30 & 25 \\
PT & 20 & 10 \\
\hline Lama sakit & & \\
\hline$<1$ th & 20 & 10 \\
2-3 th & 65 & 65 \\
$>3$ th & 15 & 25 \\
\hline Usia Responden & & \\
\hline 36-45 & 20 & 10 \\
46-55 & 70 & 75 \\
56-65 & 10 & 15 \\
\hline
\end{tabular}

Tabel 2. Distribusi Tingkat Stres

\begin{tabular}{cccc}
\hline Variabel & & Rerata & Nilai p \\
\hline \multicolumn{4}{c}{ Intervensi } \\
& Pre test & 70,85 & \\
Tingkat & Post test & 57,70 & 0,004 \\
Stres & Kontrol & & \\
& Pre test & 62,40 & \\
& Post test & 57,95 & 0,148 \\
\hline
\end{tabular}

Hasil uji paired sample t-test perbedaan Tingkat Stres pretest dan postest pada kelompok Intervensi diperoleh $p$-value $(0,004)<0,05$, artinya ada perbedaan yang signifikan Tingkat Stres pada kelompok Intervensi pre test dan postest. Hasil uji paired sample t-test perbedaan Tingkat Stres pretest dan postest pada kelompok Kontrol diperoleh $p$-value $(0,148)>0,05$, artinya Tidak ada perbedaan yang signifikan tingkat stres pada kelompok Kontrol pre test dan postest.

Hasil uji paired sample t-test perbedaan Kadar Kortisol pretest dan postest pada kelompok Intervensi diperoleh $p$-value $(0,172)>0,05$, artinya Tidak ada perbedaan yang signifikan Kadar Kortisol pada kelompok Intervensi pre test dan posttest.

Tabel 3. Distribusi Kadar Kortisol

\begin{tabular}{cccc}
\hline Variabel & & Rerata & Nilai p \\
\hline \multirow{4}{*}{ Kadar } & Intervensi & & \\
Kortisol & Pre test & 17,65 & 0,172 \\
& Post test & 11,30 & \\
& Kontrol & & \\
& Pre test & 17,65 & 0,175 \\
& Post test & 15,55 & 0,10 \\
\hline
\end{tabular}

\section{Perbedaan Tingkat Stres Pasien Yang Menjalani Hemodialisis Kelompok Intervensi dan Kontrol Setelah menjalani Self Healing}

Tabel 4. Distribusi Tingkat Stres

\begin{tabular}{ccc}
\hline Variabel & Rerata Nilai p \\
\hline Tingkat Intervensi Post Test & 57.70 & 0,004 \\
Stres $\quad$ Kontrol Post test & 57.95 & \\
\hline
\end{tabular}

Hasil uji independen t-test perbedaan Tingkat Stres postest pada kelompok Intervensi dan Kontrol diperoleh p-value $(0,004)<$ 0,05 , artinya ada perbedaan yang signifikan Tingkat Stres pada kelompok Intervensi dan Kontrol setelah menjalani Self Healing.

\section{Perbedaan Kadar Kortisol Pasien Yang Menjalani Hemodialisis Kelompok Intervensi dan Kontrol Setelah menjalani Self Healing}

Tabel 5. Distribusi Kadar Kortisol

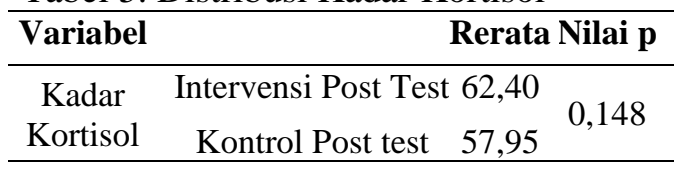

Hasil uji independen t-test perbedaan Kadar Kortisol postest pada kelompok Intervensi dan Kontrol diperoleh $p$-value $(0,148)>$ 0,05 , artinya tidak ada perbedaan yang signifikan Kadar Kortisol pada 
kelompok Intervensi dan Kontrol setelah menjalani Self Healing.

Penelitian ini dirancang untuk mengetahui perubahan tingkat stres dan kadar kortisol pada pasien hemodialisis sebelum dan sesudah diberikan self healing (Prayer) dengan menggunakan media modul Self Healing. Penelitian ini dilakukan berdasarkan penelitian sebelumnya bahwa dengan berdo'a yang dijalankan dengan benar, rutin dan ikhlas dapat meningkatkan sistem imun (Soleh, 2009). Penelitian ini dilakukan selama 4 minggu. Dengan frekuensi bimbingan 1 (satu) minggu 2 kali dengan durasi pembimbingan 25-30 menit. Berdasarkan teori adaptasi dari durasi latihan yang baik adalah dengan frekuensi latihan sebanyak 2-5 kali/minggu dan akan terjadi puncaknya pada minggu ke 6 sampai ke 8 (Geowald, 1988).

Hasil Skor DASS yang dilakukan pada 20 responden menunjukkan hasil jumlah responden pada kelompok intervensi yang tingkat stres sedang pada waktu sebelum intervensi sebanyak 13 responden (65\%) setelah dilakukan intervensi menjadi 8 responden (40\%), responden dengan stres ringan sebanyak 5 responden $(25 \%)$ setelah dilakukan intervensi menjadi 11 responden $(55 \%)$ dan pada tingkat stres berat sebanyak 2 responden (10\%) setelah dilakukan intervensi menjadi 1 responden (5\%).

Dari hasil pengolahan data dengan menggunakan SPSS 22 pada variabel skor tingkat Stres didapatkan rerata sebelum diberikan self healing ( Do'a dan zikir) adalah 70,85 dan rerata setelah diberikan self healing ( Do'a dan zikir) adalah 57,70 adapun nilap $\mathrm{p}=0,004$ Karena nilai $\mathrm{p}<0,05$ dapat disimpulkan ada perbedaan bermakna antara sebelum dan setelah diberikan self healing ( Do'a dan zikir) dengan perubahan skor tingkat stres pada pasien hemodialisis.

Sedangkan hasil Skor DASS 42 pada kelompok kontrol menunjukkan jumlah responden dengan skor tingkat stres sedang pada waktu sebelum intervensi sebanyak 11 responden (55\%) setelah dilakukan intervensi tetap 11 responden (55\%), responden dengan stres ringan sebanyak 8 responden (40\%) setelah dilakukan intervensi menjadi 9 responden $(45 \%)$ dan pada tingkat stres berat sebanyak 1 responden (5\%) setelah dilakukan intervensi menjadi 0 responden $(0 \%)$.

Dari hasil pengolahan data dengan menggunakan SPSS 22 pada variabel skor tingkat Stres kelompok kontrol didapatkan rerata 62,40 dan rerata hasil posttest 57,95 adapun nilai $\mathrm{p}=0,148$. Karena nilai $\mathrm{p}>0,05$ dapat disimpulkan tidak ada perbedaan signifikan skor tingkat stres pada pasien hemodialisis kelompok kontrol.

Hasil uji independen t-test perbedaan Tingkat Stres postest pada kelompok Intervensi dan Kontrol diperoleh $p$-value $(0,004)$ artinya ada perbedaan yang signifikan Tingkat Stres pada kelompok Intervensi dan Kontrol setelah menjalani Self Healing.

Penyakit kronis salah satu faktor risiko yang dapat menimbulkan gangguan jiwa. Pasien gagal ginjal kronis stadium akhir dapat mengalami perubahan ritme kehidupan yang bisa menjadi stresor pada dirinya. Perubahan yang dapat dialami pasien karena rasa sakitnya dapat berupa penurunan fisik, rasa nyeri, waktu pengobatan dan konsumsi obat yang dijalani dapat menjadi suatu tekanan psikologis pada pasien tersebut. Pasien dengan penyakit kronis tidak hanya mengalami perubahan pada dirinya namun juga berdampak lebih luas, 
seperti masalah ekonomi yang merupakan dampak dari kemungkinan kehilangan pekerjaan, perubahan peran dala keluarga dan rasa katakutan akan kematian (Liang J\& Chih K., 2009)

Terapi Islamic self healing merupakan suatu tindakan yang bertujuan untuk memberikan efek terapi secara islami yaitu pengobatan dengan memperkuat hati serta bersandar dan tawakal kepada Allah, mencari perlindungan, bersikap rendah hati dan memperlihatkan kelembutan hati di hadapan-Nya, memohon kepada-Nya, dan berdoa kepada Allah untuk memperoleh kesembuhan yang dilakukan dengan cara mendemonstrasikan dan memandu pasien dalam pelaksanaan terapi yang berisikan aspek hikmah dan faidah adanya sakit, doa, zikir kesembuhan dan meminum air zamzam ( Endra, EC., et.all, 2015)

Pada penelitian ini ditemukan kelompok intervensi yang masih terdapat 1 responden yang mengalami stres berat dengan jenis kelamin laki-laki berusia 56 tahun. Setelah mendapatkan hasil pememeriksaan skor DASS 42 peneliti selanjutnya melakukan identifikasi penyebab stres yang dirasakan responden tersebut. Responden tersebut setelah mendapatkan diagnosis gagal ginjal kronis dan harus menjalani dialisa dengan kondisi fisik yang semakin menurun yang membuat responden harus mengambil keputusan untuk pensiun dini dari pekerjaannya, perubahan peran sebagai seorang ayah dalam keluarga sudah tidak bisa dilaksanakan karena harus menjalani hemodialisis 1 minggu sebanyak 2 kali dan klien baru menjalani hemodialisis selama 1 bulan, sehingga stress dipengaruhi oleh perubahan peran pada pasien gagal ginjal kronis yang menjalani hemodialisis.

Secara umum hasil pengukuran kadar kortisol menunjukkan adanya penurunan. Akan tetapi terdapat 1 responden yang tidak mengalami penurunan yaitu dari $25,79 \mu \mathrm{g} / \mathrm{dL}$ menjadi 26,17 $\mu \mathrm{g} / \mathrm{dL}$. Hasil pengolahan data variabel kadar kortisol diperoleh rerata pretest sebesar 17,65 $\mu \mathrm{g} / \mathrm{dL}$ dan hasil rerata posttest $11,30 \mu \mathrm{g} / \mathrm{dL}$ dengan nilai $\mathrm{p}=0,172(\mathrm{p}>0,05)$ yang artinya tidak ada hubungan bermakna antara self healing dengan perubahan kadar kortisol pasien hemodialisis.

Pada pasien yang mengalami kenaikan kadar kortisol pada kelompok intervensi tetapi dari hasil skor DASS tetap berada dalam kategori stres berat. Hal ini di karenakan klien baru saja menjalani hemodialisis selama 2 bulan. Perubahan peran yang melekat pada dirinya telah terjadi perubahan. Selain itu akan dijelaskan terkait beberapa factor yang menyebabkan hasil penelitian yang dilakukan tidak sesuai dengan hipotesis.

Pertama adalah kontinuitas pelaksanaan zikir. Pelaksanaan zikir yang dilakukan dalam penelitian ini hanya dilakukan seminggu dua kali dan selama 4 minggu di rumah sakit, walaupun saat dirumah klien disarankan untuk melakukan setiap saat namun tidak ada pengontrolnya. Bila kegiatan self healing ini diberikan secara terus menerus selama intervensi dengan memperpanjang masa intervensi, kemungkinan dapat menurunkan kadar kortisol lebih besar sehingga aka nada hubungan yang signifikan antara self healing dengan perubahan kadar kortisol pasien hemodialisis.

\section{SIMPULAN}

a. Sebagian besar responden memiliki tingkat stres sedang 
sebelum dilakukan intervensi pemberian self healing

b. Sebagian besar kadar kortisol pasien hemodialisis dalam batas nilai normal kadar kortisol (4,30 22,40 $\mu \mathrm{g} / \mathrm{dL}$, Lab Klinik Prodia)

c. Terdapat pengaruh antara self healing terhadap tingkat stres pada pasien hemodialisis setelah dilakukan intervensi selama 4 minggu

d. Tidak terdapat pengaruh antara self healing terhadap kadar kortisol pada pasien hemodialisis setelah dilakukan intervensi selama 4 minggu

\section{SARAN}

a. Sebagai perawat ruangan diharapkan mampu melakukan bimbingan spiritual pada pasien hemodialisis dengan memanfaatkan fasilitas audio agar memberikan kenyamanan pada pasien hemodialisis

b. Diharapkan pada penelitian lebih lanjut untuk menggunakan jumlah responden yang lebih banyak dengan waktu intervensi yang lebih lama.

\section{UCAPAN TERIMAKASIH}

Dengan terselesainya penelitian ini tidak lupa peneliti mengucapkan terimakasih kepada Rektor Universitas Tanjungpura, Dekan Fakultas Kedokteran Universitas Tanjungpura, Ketua LPPKM Universitas Tanjungpura yang telah memberikan dukungan bagi peneliti untuk melakukan penelitian ini. Tak lupa juga kami sampaikan ucapan terimakasih sebesar - besarnya kepada Direktur RSUD Dokter Soedarso - Pontianak dan Direktur RSUD dr. Abdul Aziz - Singkawang yang telah memberikan kesempatan bagi peneliti dalam pengambilan data penelitian serta semua pihak yang telah memberikan kontribusi dalam penelitian ini.

\section{REFERENSI}

Black, J.M.,\&Hawks, J.H. (2009). Medical Surgical Nursing Clinical Managemen for Positive Outcome. $\left(8^{\text {th }}\right.$ ed). St. Louis: Elsevier

Damanik, Evelina Debora. (2011). The Measurement of Reliability, Validity Item Analysis and Normative Data of Depression Anxiety Stres Scale (DASS). Thesis Fakultas Psikologi Universitas Indonesia : Depok

Echder T, Schriner RW. (2012). Cardiovascular Abnormalities in Autosomal Dominant Polistic Kidney Disease. Nat Rev Nephrol

Egan R., Wood S., Macleod R, \& Walker R., 2015, Spirituality In Renal Supportive Care : A Thematic Review Journal Health Care 3; 1174-1193

Geowald E.R \& Luck. 1988. The Healing Power of Doing Good. Reader's Digest

Harris A, Secki R. 2011. Glucocorticoids, prenatal stress anda the programming of disease. Media Medika Indonesia. 56 93): 27889

Kemenkes RI. (2017). Profil Kesehatan Indonesia 2016. Jakarta : Kemenkes RI

Kim, Y., Evangelista I.S., Phillips, L.R., Pavlish C.,\& Kopple, J.D. (2010). The End - Stage Renal Disease Adherence Questionnaire (ESRD-AQ): Testing yhe psychometric properties in patients receiving in- center hemodialysis, Nephrology Nursing Journal, 37 (4), 377-393 
Liang J\& Chih K. 2009. The Psychological Impact of Hemodialysis on Patient With Chronic Renal Failure. Chang Gung University of Medicine Taiwan

Maimunah, Annisa \&Retnowati, Sofia. (2011). Pengaruh Pelatihan Relaksasi dengan Zikir Untuk Mengatasi Kecemasan Ibu Hamil Pertama. Psikoislamika Jurnal Psikologi Islam Vol. 8 No.1: 122

PERNEFRI. (2017). 10 $10^{\text {th }}$ Report Of Indonesia Renal Registri 2017. http://.penefri.inasn.org/gallery. $\underline{\mathrm{html}}$

S. Suryani\&A. Nuraeni. 2015. Pengaruh Relaksasi Zikir Terhadap Tingkat Kecemasan Pasien Gagal Ginjal yang Mengaami Hemodialisis. Jurnal Keperawatan UNPAD 3 (1)

Sandra, Dewi W.N.,\&Dewi Y.L.,2012. Gambaran Stres Pada Pasien Gagal Ginjal Terminal Yang Menjalani Terapi Hemodialisis di RSUD Arifin Achmad Pekan Baru. Jurnal Ners Indonesia 2(2).Hal 99-108

Smeltzer, S.C., \& Bare. B.G., (2009). Texbook of medikal surgical nursing $\left(11^{\text {th }}\right.$ ed).Philladelphia: Lipincott Williams \& Wilknis

Terri, C.J\& Glenwick, D.S., 2013. The Relationship of Religious And General Coping to Psychological Adjusment and Distres in Urban Adolescent. J. Religi Health.52;1188-1202

Yosep I.(2014). Keperawatan Jiwa. Bandung: Refika Aditama 